\title{
Variation in intracellular $P^{1} P^{4}$-bis $\left(5^{\prime}\right.$-adenosyl) tetraphosphate $\left(\mathrm{Ap}_{4} \mathrm{~A}\right)$ in virus-infected cells
}

\author{
David J. JOHNSTON, ${ }^{*}$ C. Anthony HART $\dagger$ and Alexander G. McLENNAN* $\ddagger$ \\ *Department of Biochemistry and †Department of Medical Microbiology, University of Liverpool, P.O. Box 147, \\ Liverpool L69 3BX, U.K.
}

\begin{abstract}
The effect of virus infection on the intracellular concentration of the proposed stress alarmone $P^{1} P^{4}$-bis $\left(5^{\prime}\right.$-adenosyl) tetraphosphate $\left(\mathrm{Ap}_{4} \mathrm{~A}\right)$ has been examined in Vero cells. Compared with exposure to $0.8 \mathrm{~mm}-\mathrm{Cd}^{2+}$, which causes a 30 -fold increase in $\mathrm{Ap}_{4} \mathrm{~A}$, infection with simian virus 40 and poliovirus causes only a 2-fold increase, whereas herpes simplex virus type 1 results in a decrease in $A_{4} A$ during the course of the infection.
\end{abstract}

\section{INTRODUCTION}

The dinucleotide $P^{1} P^{4}$-bis( $\left(5^{\prime}\right.$-adenosyl) tetraphosphate $\left(\mathrm{Ap}_{4} \mathrm{~A}\right)$ is present in prokaryotic and eukaryotic cells in submicromolar to micromolar concentrations and may be involved in a number of intracellular processes (Zamecnik, 1983; Grummt, 1988). Despite its ability to bind to and prime eukaryotic DNA polymerase- $\alpha$ in vitro (Baril et al., 1985), the original proposal that it is involved in the initiation of DNA replication in eukaryotes is not supported by more recent observations: the 100-1000-fold increases in its intracellular concentration which precede the onset of S-phase in some situations have not been universally observed (McLennan \& Prescott, 1984; WeinmannDorsch et al., 1984; Garrison et al., 1986; Moris et al., 1987).

An alternative role for $\mathrm{Ap}_{4} \mathrm{~A}$ and related nucleotides, as alarmones signalling the onset of metabolic stress, was proposed following the observation that, in Escherichia coli and Salmonella typhimurium, the levels of these nucleotides increased dramatically following exposure to heat shock, heavy metals and oxidizing agents (Lee et al., 1983a,b; Bochner et al., 1984). However, in eukaryotes, the changes in the concentrations of $\mathrm{Ap}_{4} \mathrm{~A}$ and other dinucleotides after such treatments are generally of the order of 2-3-fold (Miller \& McLennan, 1986; Guédon et al., 1986); the 100-1000-fold increases typical of $E$. coli and $S$. typhimurium are only observed after treatment with lethal doses of stressors and are therefore not thought to be of physiological importance (Baltzinger et al., 1986). Nevertheless, a 2-3-fold change in the steady state concentration of an intracellular effector molecule could still be of great significance, particularly if the molecule is part of a signal amplification mechanism such as a cyclic cascade.

No information exists on the behaviour of $\mathrm{Ap}_{4} \mathrm{~A}$ during virus infections; however, certain considerations would appear to justify such an investigation. First, any molecule which plays an important role in cellular metabolism may be required to a greater or lesser extent by certain viruses for successful infection and therefore deserves consideration as a potential target for new anti-viral compounds. Secondly, the possible involvement of $\mathrm{Ap}_{4} \mathrm{~A}$ in cellular DNA replication suggests that it may also be required by viruses such as simian virus 40 (SV40) which rely extensively on host cell DNA replication mechanisms; on the other hand, RNA viruses and large DNA viruses such as herpes simplex virus type 1 (HSV-1) that replicate largely independently of host cell factors may have no requirement for $\mathrm{Ap}_{4} \mathrm{~A}$. Finally, as viral infection may be regarded as an extreme form of cellular stress, this may be reflected in changes in the concentrations of $\mathrm{Ap}_{4} \mathrm{~A}$ and other dinucleotides after infection. Therefore, as part of our studies into the function of $\mathrm{Ap}_{4} \mathrm{~A}$, we have determined the intracellular level of this compound in Vero cells at various times after infection with SV40, HSV-1 and poliovirus.

\section{MATERIALS AND METHODS}

\section{Materials}

Vero African green monkey kidney cells, medium 199 (Earle's salts) and foetal calf serum were from Gibco U.K. [methyl$\left.{ }^{3} \mathrm{H}\right]$ Thymidine $(40-60 \mathrm{Ci} / \mathrm{mmol})$ and $\left[5-{ }^{3} \mathrm{H}\right]$ uridine $(25-30$ $\mathrm{Ci} / \mathrm{mmol}$ ) were from Amersham International. Calf intestine alkaline phosphatase and snake venom phosphodiesterase were obtained from Boehringer. Phosphate-buffered saline (PBS) contained $100 \mathrm{~g}$ of $\mathrm{NaCl}, 2.5 \mathrm{~g}$ of $\mathrm{KCl}, 14.375 \mathrm{~g}$ of $\mathrm{Na}_{2} \mathrm{HPO}_{4}$ and $2.5 \mathrm{~g}$ of $\mathrm{KH}_{2} \mathrm{PO}_{4}$ per litre. All other materials were as previously described.

\section{Viruses}

SV40, Toronto strain, was a gift from the Institute of Virology, University of Glasgow. HSV-1 (strain HFEM) and poliovirus (Sabin: type 1) were from stocks held in the Department of Medical Microbiology, University of Liverpool, that had been stored at $-70^{\circ} \mathrm{C}$ until use.

\section{Infection of cells and radiolabelling}

Vero cells were grown in $75 \mathrm{~mm}^{2}$ flasks at $37^{\circ} \mathrm{C}$ in medium 199 supplemented with $5 \%(\mathrm{v} / \mathrm{v})$ foetal calf serum in an atmosphere of air $/ \mathrm{CO}_{2}(19: 1)$. For virus infections, cells were grown to confluence as above in $50 \mathrm{~mm}$ dishes in medium supplemented with $100 \mu \mathrm{g}$ of streptomycin $/ \mathrm{ml}$ and 100 units of penicillin $/ \mathrm{ml}$. After a further 2 days, the medium was removed and the cells were infected with 10 plaque-forming units (p.f.u.) of virus/cell in $1 \mathrm{ml}$ of maintenance medium [medium 199 supplemented with $1.7 \%(\mathrm{v} / \mathrm{v})$ foetal calf serum]; mock infections were with $1 \mathrm{ml}$ of maintenance medium alone. After a $30 \mathrm{~min}$ adsorption period, the medium was replaced with $10 \mathrm{ml}$ of fresh maintenance medium and the infected cells were harvested at various times thereafter for the determination of $\mathrm{Ap}_{4} \mathrm{~A}$.

Abbreviations used: $\mathrm{Ap}_{4} \mathrm{~A}, P^{1} P^{4}$-bis(5'-adenosyl) tetraphosphate; $A \mathrm{p}_{4} \mathrm{~N}$, adenosine $5^{\prime}-P^{1}$-tetraphospho- $P^{4}-5^{\prime \prime \prime}$-nucleoside; SV40, simian virus 40 ; HSV-1, herpes simplex virus type 1; PBS, phosphate-buffered saline; p.f.u., plaque-forming unit(s).

$\ddagger$ To whom correspondence should be addressed. 
For the measurement of DNA or RNA synthesis, dishes contained $4 \times 14 \mathrm{~mm}$ glass coverslips, and cells were pulselabelled for periods of $30 \mathrm{~min}$ or $1 \mathrm{~h}$ at various times after infection by replacement of maintenance medium with $10 \mathrm{ml}$ of fresh maintenance medium containing $2 \mu \mathrm{Ci}$ of $\left[{ }^{3} \mathrm{H}\right]$ thymidine $/ \mathrm{ml}$ for SV40 and HSV-1 or $2 \mu \mathrm{Ci}$ of $\left[{ }^{3} \mathrm{H}\right]$ uridine/ml plus $1 \mu \mathrm{g}$ of actinomycin $\mathrm{D} / \mathrm{ml}$ for poliovirus (Zimmerman et al., 1963). After labelling, the medium was removed and the plates were washed with PBS (twice), 5\% (w/v) trichloroacetic acid $(3 \times 5 \mathrm{~min})$, water and absolute ethanol (twice). The plates were left to dry for $24 \mathrm{~h}$, and the coverslips were then removed and counted for radioactivity in $8 \mathrm{ml}$ of toluene-based scintillant.

Cells were counted in a haemocytometer after trypsin treatment.

\section{Measurement of $\mathbf{A p}_{\mathbf{4}} \mathbf{A}$}

After removal of medium, cell monolayers were washed quickly with $5 \mathrm{ml}$ of cold PBS and drained. Ice-cold $10 \%(\mathrm{w} / \mathrm{v})$ trichloroacetic acid $/ 5 \mathrm{mM}$-EDTA $(5 \mathrm{ml})$ was then added to each dish and the cells were scraped from the dishes. The cell suspensions were then centrifuged at $23500 \mathrm{~g}_{\mathrm{av}}$. for $15 \mathrm{~min}$ and the supernatants were adjusted to $\mathrm{pH} 9.0$ with conc. ammonia solution and to $1 \mathrm{M}$-ammonium acetate by the addition of $6 \mathrm{M}$ ammonium acetate, $\mathrm{pH}$ 9.0. Purification of a fraction containing nucleotides of the form $\mathrm{Ap}_{4} \mathrm{~N}$ from these cell extracts was performed by affinity chromatography on dihydroxyl-BioRex 70 as described by Baker \& Jacobson (1984). For the determination of $\mathrm{Ap}_{4} \mathrm{~N}$, the freeze-dried eluates were dissolved in $800 \mu \mathrm{l}$ of assay buffer [35 mM-Hepes/KOH ( $\mathrm{pH} \mathrm{7.8)/7} \mathrm{mM-magnesium}$ acetate] containing 0.4 units of alkaline phosphatase and incubated for $30 \mathrm{~min}$ at $37^{\circ} \mathrm{C}$. ATP-monitoring reagent $(200 \mu \mathrm{l})$ (Pharmacia-LKB) was then added, followed by $1.5 \mu \mathrm{g}$ of snake venom phosphodiesterase, and the increase in luminescence was recorded with an LKB 1250 Luminometer (McLennan \& Prescott, 1984).

\section{RESULTS AND DISCUSSION}

The assay system employed does not distinguish between bis $\left(5^{\prime}\right.$-nucleosidyl) oligophosphates in which both bases are adenine (e.g. $\left.\mathrm{Ap}_{4} \mathrm{~A}\right)$ and those containing a single adenine [e.g. adenosine $5^{\prime}-P^{1}$-tetraphospho- $P^{4}-5^{\prime \prime \prime}$-nucleoside $\left(A_{4} N\right)$ ]. However, since the major bis( $5^{\prime}$-nucleosidyl) oligophosphate in mammalian cells is $\mathrm{Ap}_{4} \mathrm{~A}$ and the assay is twice as sensitive to $\mathrm{Ap}_{4} \mathrm{~A}$ as to $A p_{4} N$, the level of $A p_{4} N$ can be taken to reflect that of $\mathrm{Ap}_{4} \mathrm{~A}$ (Moris et al., 1987). In order to show that the extraction and assay procedures employed were able to detect differences in the cellular levels of nucleotides, a positive control system was required. The most satisfactory and reproducible control, which was included with each viral infection, involved treatment of confluent monolayers of Vero cells with $0.8 \mathrm{~mm}$-cadmium acetate. Fig. 1 shows that this resulted in a time-dependent increase in the level of $\mathrm{Ap}_{4} \mathrm{~N}$, with the maximum 30-fold increase being reached after $4 \mathrm{~h}$ of exposure. By $6 \mathrm{~h}$ the level had declined substantially, reflecting the fact that the cells had been killed by the toxic $\mathrm{Cd}^{2+}$ ions. This result is similar to that described by others (Baker \& Jacobson, 1986; Baltzinger et al., 1986; Coste et al., 1987).

For all viral infections, cells which had been in a confluent state for 2 days were used. These yielded values of $0.40 \pm 0.10$ pmol of $A p_{4} N / 10^{6}$ cells. Upon infection with SV40, a time-dependent increase in DNA synthesis was observed (Fig. 2). Although separate measurements of host cell and viral DNA synthesis were not made, it is likely that the early increase $(10-20 \mathrm{~h})$ is due predominantly to the induction of host cell DNA replication, whereas later thymidine incorporation (20-36 h) represents mainly viral DNA synthesis (Ritzi \& Levine,

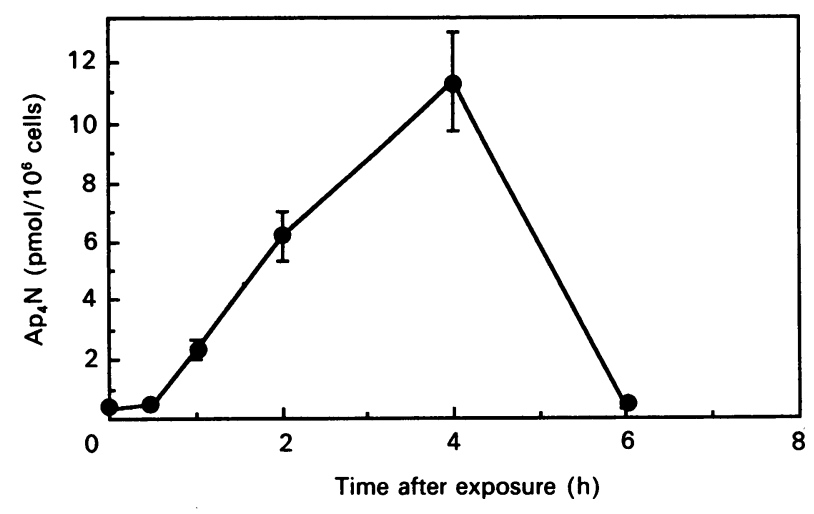

Fig. 1. Effect of $\mathrm{Cd}^{2+}$ on the $\mathrm{Ap}_{4} \mathrm{~N}$ content of Vero cells

Cell monolayers were treated with $10 \mathrm{ml}$ of maintenance medium containing $0.8 \mathrm{~mm}$-cadmium acetate for various times and the $A_{4} \mathrm{~N}$ content was measured as described in the Materials and methods section. Values are means \pm S.D. derived from three independent experiments.

1970; DePamphilis \& Wassarman, 1982). During this time, the intracellular concentration of $\mathrm{Ap}_{4} \mathrm{~N}$ showed a small but significant $(P=0.01) 2$-fold increase up to $16 \mathrm{~h}$ compared with mock-infected cells, with a subsequent decline during the period of peak viral DNA synthesis.

In contrast to SV40, which induces host DNA replication, infection with HSV-1 causes a rapid cessation of host DNA synthesis (Roizman, 1969). Fig. 3 shows that viral DNA synthesis in Vero cells commences about $4 \mathrm{~h}$ post-infection with maximum synthesis around 10-12 h (somewhat later than in other host cell systems). In this case, $\mathrm{Ap}_{4} \mathrm{~N}$ levels show little change, although there is some indication of a gradual loss $(P=0.1)$ throughout the growth cycle. At later times this may be due in part to the loss of detached cells during washing of the monolayers, though this could account for only about $10-15 \%$ of the decrease.

In view of the previously suggested association of $A_{4} A$ with DNA replication, it might be concluded that the changes in $A p_{4} \mathrm{~N}$ observed above are related to the levels of host cell DNA synthesis. However, poliovirus infection, which inhibits the low

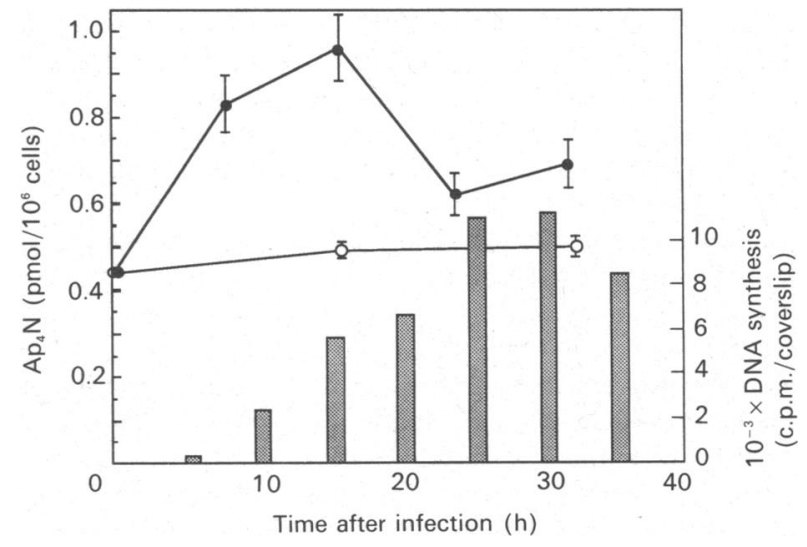

Fig. 2. Effect of infection by $\mathrm{SV} 40$ on the $\mathrm{Ap}_{4} \mathrm{~N}$ content of Vero cells

Cell monolayers were infected $(O)$ or mock-infected $(O)$ and $A p_{4} N$ was extracted and measured as described in the Materials and methods section. Values are means \pm S.D. derived from three independent experiments. For each time point, duplicate dishes containing four glass coverslips were used for the determination of $\left[{ }^{3} \mathrm{H}\right]$ thymidine incorporation as described in the Materials and methods section (bars). 


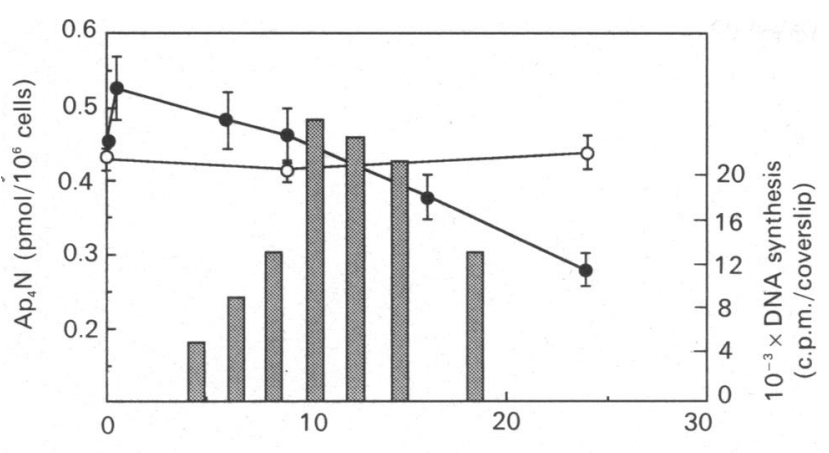

Time after infection (h)

Fig. 3. Effect of infection by $\mathrm{HSV}-1$ on the $A p_{4} \mathrm{~N}$ content of Vero cells

Cell monolayers were infected $(O)$ or mock-infected $(O)$ and $A_{4}{ }_{4} N$ was extracted and measured as described in the Materials and methods section. Values are means \pm S.D. derived from three independent experiments. For each time point, duplicate dishes containing four glass coverslips were used for the determination of $\left[{ }^{3} \mathrm{H}\right]$ thymidine incorporation as described in the Materials and methods section (bars).

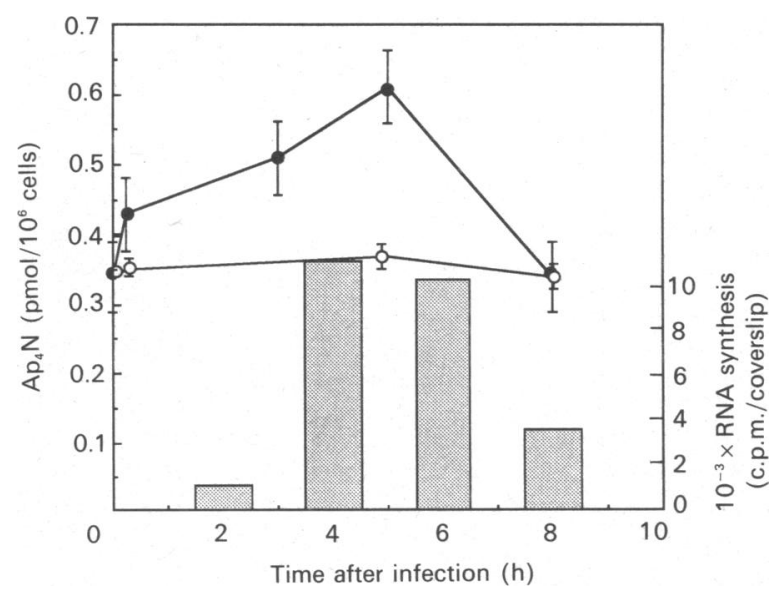

Fig. 4. Effect of infection by poliovirus on the $\mathrm{Ap}_{4} \mathrm{~N}$ content of Vero cells

Cell monolayers were infected $(O)$ or mock-infected $(O)$ and $A_{p_{4}} N$ was extracted and measured as described in the Materials and methods section. Values are means \pm S.D. derived from three independent experiments. For each time point, duplicate dishes containing four glass coverslips were used for the determination of actinomycin D-resistant $\left[{ }^{3} \mathrm{H}\right]$ uridine incorporation as described in the Materials and methods section (bars). level of host DNA replication remaining in the confluent cell monolayers as a consequence of the inhibition of host protein synthesis (results not shown), causes a 2-fold increase $(P=0.02)$ in $\mathrm{Ap}_{4} \mathrm{~N}$ during the period of viral RNA synthesis (Fig. 4). In no case is there an obvious correlation with host cell RNA or protein synthesis, both of which are inhibited by infection with HSV-1 and poliovirus but stimulated by SV40, or with known patterns of synthesis of virus-specific macromolecules.

In conclusion, small but significant changes in the intracellular concentration of $\mathrm{Ap}_{4} \mathrm{~N}\left(\mathrm{Ap}_{4} \mathrm{~A}\right)$ have been observed upon infection of monkey kidney cells with different viruses. Until such time as a clearer picture emerges of the function of $A_{4} A$ in uninfected cells, the significance of these observations remains uncertain. However, they are consistent with the view that the level of $\mathrm{Ap}_{4} \mathrm{~A}$ does not readily correlate with that of DNA synthesis.

This work was supported by a grant from the Wellcome Trust.

\section{REFERENCES}

Baker, J. C. \& Jacobson, M. K. (1984) Anal. Biochem. 141, 451-460

Baker, J. C. \& Jacobson, M. K. (1986) Proc. Natl. Acad. Sci. U.S.A. 83, 2350-2352

Baltzinger, M., Ebel, J.-P. \& Remy, P. (1986) Biochimie 68, 1231-1236

Baril, E. F., Coughlin, S. A. \& Zamecnik, P. C. (1985) Cancer Invest. 3, 465-471

Bochner, B. R., Lee, P. C., Wilson, S. W., Cutler, C. W. \& Ames, B. N. (1984) Cell 37, 225-232

Coste, H., Brevet, A., Plateau, P. \& Blanquet, S. (1987) J. Biol. Chem. 262, 12096-12103

DePamphilis, M. L. \& Wassarman, P. M. (1982) in Organization and Replication of Viral DNA (Kaplan, A. S., ed.), pp. 37-114, CRC Press Inc., Boca Raton, Florida

Garrison, P. N., Mathis, S. A. \& Barnes, L. D. (1986) Mol. Cell. Biol. 6 , 1179-1186

Grummt, F. (1988) in Modern Cell Biology (Satir, B. H., ed), vol. 6, pp. 29-64, Alan R. Liss, Inc., New York

Guédon, G. F., Gilson, G. J. P., Ebel, J. P., Befort, N. M.-P. \& Remy, P. (1986) J. Biol. Chem. 261, 16459-16465

Lee, P. C., Bochner, B. R. \& Ames, B. N. (1983a) Proc. Natl. Acad. Sci. U.S.A. 80, 7496-7500

Lee, P. C., Bochner, B. R. \& Ames, B. N. (1983b) J. Biol. Chem. 258, 6827-6834

McLennan, A. G. \& Prescott, M. (1984) Nucleic Acids Res. 12, 1609-1619

Miller, D. \& McLennan, A. G. (1986) Nucleic Acids Res. 14, 6031-6040

Moris, G., Meyer, D., Orfanoudakis, G., Befort, N., Ebel, J.-P. \& Remy, P. (1987) Biochimie 69, 1217-1225

Ritzi, E. \& Levine, A. J. (1970) J. Virol. 5, 686-692

Roizman, B. (1969) Curr. Top. Microbiol. Immunol. 49, 1-79

Weinmann-Dorsch, C., Hedl, A., Grummt, I., Albert, W., Ferdinand, F.-J., Friis, R. R., Pierron, G., Moll, W. \& Grummt, F. (1984) Eur. J. Biochem. 138, 179-185

Zamecnik, P. C. (1983) Anal. Biochem. 134, 1-13

Zimmerman, E. F., Heeter, M. \& Darnel, J. E. (1963) Virology 19, $400-408$ 